\title{
Revealed Medicine as an Expression of an African Christian Lived Spirituality
}

\author{
Carl Sundberg
}

Tropical Africa is often mediated through televised news programs and the printed press as a region where plagues, famine, and wars dominate the suffering populations. Very seldom we see reports on other parts of the social realities in which people live. During my years in both Congos, I have met people from various Christian denominations and visited fast growing Christian congregations that engage in a diversity of activities for the benefit of the societies in which they operate. Some denominations run schools and hospitals in areas where governmental health-care and schooling does not suffice. Many parishes have health centers and nutrition projects for those that have lost everything except their lives. Quite a few of these centers have been established on the basis of revelations and dreams. As will be shown below, the Kongo people traditionally live in two worlds: the "day world" and the "night world."1 What is experienced in the night world may well be realized in the day world. Dreaming of a health clinic may result in the construction of one.

In this chapter, based on fieldwork carried out in Brazzaville, in the Republic of Congo, I present the results of my studies of a method of healing that was revealed during and after the spiritual Revival of 1947 (described below), in today's Evangelical Church of Congo: a method referred to as the Revealed Medicine.

Between 1982 and 2010, I periodically lived and worked in Brazzaville as a missionary pastor and teacher in the Eglise Evangélique du Congo (EEC). Like many other Westerners I have suffered from malaria, parasites, wounds, and other illnesses, and I have met with several people suffering from diseases that I have never even heard of. Naturally I have been interested in finding out what people do to get well. There are a few state-owned hospitals in Brazzaville and

1 Kongo, with a K, (sometimes written Kôngo) signifies the peoples originating from the former Kongo Kingdom located in what is now the western part of the Republic of Congo, the Democratic Republic of Congo, and Angola. 
the Chinese government has tried to establish well-equipped hospitals, which are much liked, but since a large percentage of the population is very poor, cheap solutions are widely sought. At the Bacongo market one can find many different kinds of antibiotics, most of which are probably fake. People buy them by the capsule and eat as many as they can afford, very often too few. I have met with charismatics who cure people's wounds with la pierre noire and prayer. A piece of black petrified wood boiled in milk is applied to the wound and fixed in place with a bandage. The charismatic prays to draw out the evil spirits. When the "black stone" falls off, the wound is healed. I have also met with people who have told me that they suffer from $M b a z u$, an illness, according to my informant, caused by "a very nasty fetish that kills the one it is destined to kill and wounds other people who come near it. Mbazu can only be cured through sessions of prayer with a charismatic healer having the gift to heal that specific illness."

Brazzaville is a multicultural and multi-religious melting pot. People search for very pragmatic solutions to their everyday problems, and these solutions are often believed to be found in charismatic independent churches and prayer groups, where healing and exorcisms are carried out. Modern forms of fetishism and sorcery also exercise influence as protection is needed and pursued. ${ }^{3}$ In this setting, the therapeutic centers of the Revealed Medicine offer low-cost treatment and healing to anyone seeking to get well, practiced in the same way whether offered at a local parish or at a bigger center. It is holistic in its perspective and the personnel take care to examine not only the illness of the client but also his/her social status and setting. The religious foundation is that God loves human beings and wants them to be well and to function in society, and it is manifest that it is God who heals. The treatment and medicines are only the means by which healing occurs. Without the religious ceremonies counseling, intercession, and dialogue - the medicines in themselves are ineffective.

The focus of my work is to see how the Revealed Medicine originates and develops in the tension between the Kongo's traditional values and expressions, today's expressions of Christian faith, and also in competition with the "Western medicine" of modern society. In this chapter, I evaluate the sustainability of the Revealed Medicine as a low-cost panacea accessible to all, and discuss whether it is to be seen as the Christianization and adaptation of

2 Interview, February 2000, Albert Mutinu, driver.

3 Carl Sundberg, Conversion and Contextual Conceptions of Christ-A missiological study among young converts in Brazzaville, Republic of Congo. (Studia Missionalia Svecana LXXXI, Uppsala, 2000), 26. 
"traditional healing" to a modern Christian setting, offering a re-reading of a traditional method.

An introduction of the Bakongo worldview provides the background necessary to understand how the Kongo conceive of illness and healing, and information on the traditional views of medicine and magic. Thereafter I present the Revealed Medicine - or "healing through the distribution of revealed leaves", from its beginning up until my 2016 fieldwork. The paper ends with a discussion of the possible paths or outcomes of the Revealed Medicine. Will it cease to exist or is there a future for the God-given treatment and medication as expressions of a lived-out Christianity in the rapidly changing Congolese society?

I know a lot of people in Brazzaville. Many are used as informants. To simplify things and assure the anonymity of everyone that took part in an interview, I have changed their names. Mostly they themselves proposed an alternative name that corresponds with their ethnic belonging. Quite a few students of the Faculty of Theology of the Protestant University of Congo, in Brazzaville, have written Masters and Licentiate papers on the revival and that material has also been used. In addition, I have relied on my own fieldnotes and partially transcribed, digitally taped, interviews with informants.

\section{Elements of Kongo Cosmology}

Every so often we are reminded that worldviews are not rapidly exchanged. A Congolese who moves to secular southern Sweden does not immediately, or even after quite a long time, change his ideas about why certain things happen or how the elements of life interact. Every society has a conception of existence, a worldview. There is a perception of the global (all that is created), in which we place and arrange humans, animals, plants, and inanimate things. At the same time, according to Wyatt MacGaffey, this cosmology is not a set of fixed axioms but varies and undergoes change as social structures are transformed. ${ }^{4}$ Meredith McGuire confirms this in Religion, the Social Context, and adds that in "modern societies religious meaning systems compete with many other worldviews. Individuals are less likely to use any single comprehensive meaning system but may apply religious meanings to segments of their lives." ${ }^{5}$

4 Wyatt MacGaffey, Religion and Society in central Africa: The Bakongo of Lower Zaïre (Chicago: University of Chicago Press 1986), 5 .

5 Meredith B. McGuire, Religion, the social context, (Belmont, CA: Wadsworth Publishing Company, 1992), 28. 
Many African scholars underline that a characteristic feature of Bantu worldviews is that all things belong to one of two worlds, the visible or the invisible. ${ }^{6}$ The visible world consists of the sky, the earth, and all the material things familiar to man. The invisible world consists of the heavenly realm, home of Nzambi (the Creator and sustainer of life) and a number of deities, and the "spirit sphere" where ancestors, spirits, and disembodied spirits dwell. ${ }^{7}$ This world is located in the ground. Following this model, the Bantu, and even more specifically, the Kongo, do not see a fixed border between the two worlds; rather, they exercise power and influence on, and to some extent, overlap, each other. "One is the carbon copy of the other", says Emefie Ikenga Metuh, a late Nigerian scholar. ${ }^{8}$ The Kongo have a very holistic understanding of everything. All is intertwined and, as Magesa puts it, quoting Baudin, "[t]he world of forces is held like a spider's web of which no single thread can be caused to vibrate without shaking the whole network."

The individual, says John Mbiti, "is immersed in a religious participation which starts before birth and continues after his death... [Hence] to live is to be caught up in a religious drama."10 Although these words were written some 40 years ago, I dare say they are still valid today.

In October 2014 I took part in a number of meetings at the Hôpital de Dieu in Brazzaville. A rather well-to-do woman had come to the center to receive treatment for her inability to get the travel documents required for a longer business trip to Europe and Asia. She, like everybody else, was received with respect and followed a fourteen-day treatment, including potions and therapeutic talk; at the end of her treatment she provided a testimony that "the

$6 \quad$ See for instance: John Mbiti, African religions and Philosophy (London, Ibadan, Nairobi: Heinemann, 1969); The use of the word "bantu" is not problematic, since mu-ntu in Kikongo means "man" and ba-ntu means "people."

7 When the Christian mission came, with the Portuguese mission directed by Diego Caô, in 1493, the missionaries adopted the already existing name of God, Nzambi, or variations of this word. This has been commented by Ragnar Widman, Trosföreställningar i Nedre Zaïre från 1880-talet (Falköping: Gummessons, 1979); Raphaël Batsikama ba Mpuya ma Ndawla, L'Ancien Royaume du Congo et les baKongo (Paris: L'Harmattan, 1999).

8 Emefie Ikenga-Metuh, The shattered Microcosm: a critical survey of explanations on conversion in Africa. Paper presented at the Religion, Development and African Identity Conf. Uppsala, 16-21st of Aug. 1984. (1987), 51.

$9 \quad$ Pierre Baudin, Fetishism and Fetish worshippers (New York: Benzinger Brothers, 1885). Quoted in Laurenti Magesa, African religion: The moral traditions of abundant life (Maryknoll, N.Y. Orbis Books), 46. 
treatment had given her peace of mind and had dissolved various problems and that she now was 'free' to travel - thanks be to God."11

\section{$3 \quad$ Medicine and Magic ${ }^{12}$}

Concerning the origin of disease/illness the Kongo propose three causes: natural, unnatural, and supernatural. The natural disease lasts only for a short period of time and the patient gets well. Natural illness can be cured by simple therapies, often using pharmaceutical products, which can be easily found in marketplaces or pharmacies. ${ }^{13}$ The patient with an unnatural disease does not easily recover, or repeatedly gets ill with the same disease. Thus, any chronic or alarming illness which resists treatment or occurs suddenly is considered unnatural and is often seen as caused by, or indicating a tension or social conflict among, members of the kanda (the extended family or clan), or even by a disequilibrium between the living and the living-dead (ancestors). Unnatural sickness can also be caused by the breaking of various taboos or by somebody exercising sorcery or witchcraft against the patient. ${ }^{14}$ Since this illness covers every aspect of human life (biological, psychological or spiritual, social, and cultural) it can only be treated with pharmaceutical products in combination with medicines containing a supernatural force. The patient is thus treated pharmaceutically and psycho-therapeutically at the same time. ${ }^{15}$ From this it follows that the treatment of an unnaturally sick patient not only considers the patient but also the whole kanda. The third type of illness, kimbevo kia Nzambi (sickness from God) has its origin in Nzambi and covers every illness due to old age or illnesses that cannot be cured. Then it is said that "Nzambi has eaten him", or that it has been Nzambi's will. ${ }^{16}$

Quite a few symptoms which are not considered illness or diseases in Western society may well be considered and treated as such among the Kongo. This

\footnotetext{
11 Fieldnotes, October 2014.

12 This section is condensed from my doctoral thesis, Sundberg, Conversion.

13 However, many prescribed medicines are often misused or used for too short a period to have the desired effect. This is mainly due to their high cost and the lack of money.

14 For profound descriptions of sorcery and witchcraft, see Eric de Rosny, L'Afrique des guérisons (Paris: Editions Karthala, 1992) and Peter Geschiere, Witchcraft, Intimacy and Trust (Chicago: University of Chicago Press, 2013).

15 Kimpianga Mahaniah, La maladie et la guérison en milieu Kongo (Kinshasa: EDICVA, 1982), 28f. Mahania is Professor of History at the Free University of Luozi, Democratic Republic of Congo.

16 Karl E. Laman, "The Kongo II," in Studia Ethnographica Upsaliensia, vol viII, ed. Sture Lagerkrantz (Uppsala: Almkvist Wiksell, 1957), 78.
} 
is related to the fact that everything which disturbs or weakens a person's "life force" (makindangolo), is seen as disturbing the life force of the kanda. Besides various illnesses caused by sorcery and malediction we find, in Mahaniah's list of diseases, "social problems" classed as supernatural or abnormal. He writes: "Kimbevo kia sanse (diseases of chance): Thus are classed problems such as the loss of a trial at court; Having been by-passed and not given a higher position at work. Or just having 'bad luck' ... Muntu kabakanga salu ko: Man couldn't keep a job."17

The above mentioned episode of the woman who was unable to get her travel papers in order is a good example of how something many outsiders would not consider an "illness" could be treated at a therapeutic center in Brazzaville as a kimbevo kia sanse, a supernatural illness. These illnesses must be treated by a person with a special gift or power to cure them, the nganga in Kongo society, and its overall priest, healer, psychologist, advocate, and stabilizer.

\section{Revealed Medicine - or "Healing through the Distribution of Revealed Leaves"}

\subsection{Historical Background}

The EEC has its roots in the mission of the Mission Covenant Church of Sweden, the Svenska Missionsförbundet, which began in 1906 when Swedish missionaries in the then Congo Freestate, later the Belgian Congo, crossed the border and the mountains separating the two Congos from each other. The revival of 1947 occurred at a time when the mission church was undergoing a crisis. "The revival broke out at the seminar, among the students, at the seat of the mission, the place where the young got their education."18 After a long period of ethnic unrest, local political instability, and opposition to the colonizing power, the church found itself in a state of decline due to growing materialism and people turning away from Christ. ${ }^{19}$ With the revival came a spiritual renewal during which a number of gifts were bestowed by the Holy Spirit, including two that receive special attention here: the gift of healing and the gift of writing. ${ }^{20}$

17 Mahaniah, La Maladie, 40, 44.

18 Efraim Andersson, Väckelse och andra kristna folkrörelser i Kongo, in Missio, vol 12, ed. Gösta Stenström, (Uppsala: Svenska Institutet frö Missionsforskning), 84.

19 Andersson, Väckelse, 84.

20 For more on the revival, see: Bertil Åhman, Daniel Ndoundou, väckelseledare $i$ den Evangeliska kyrkan i Kongo. Studia Missionalia Svecana CXIII (Uppsala, 2014); Sundberg, 


\subsection{Daniel Ndoundou and the Gift of Healing}

As early as 1931, Daniel Ndoundou, a charismatic pastor of the EEC, had a vision in which God indicated a place outside of Ngouédi, in Mfouati, at the base of a waterfall, where he was to dam up water and create a Kizinga kia Siloa (a pond of Siloa - see the Gospel of John 9:7) into which people were to dip themselves in order to be healed. ${ }^{21}$ However, it was not until December 1972 that the project was realized and the dam was inaugurated. Interestingly later therapeutic centers are often referred to as kizinga.

In August 1948, Ndoundou prayed for a lame boy during a public service and the boy was healed. Then, in 1949, Ndoundou, together with two laypeople, received the spiritual gift to heal people with medicines (tisanes/infusions) prepared by boiling the roots, stems, or leaves of various plants in water. ${ }^{22}$ Daniel Ndoundou attracted hundreds, if not thousands of people, who came to him for treatment. Other gifts of healing were administered by the Holy Spirit to further Christians in the coming months along with gifts that were related to the that of healing, namely: "the gift of seeing" in which the charismatic can give a diagnosis and see the fundamental causes of an illness; "the gift of tisane" in which the charismatic receives the recipe for medicine to distribute, individually, to each patient; and the "gift of intercession" which allows the charismatic to plead with God to heal the client using the medication prescribed. Occasionally the gift of direct healing was also given which worked an immediate healing through prayer only. ${ }^{23}$ In 1968 , twenty years later, the first center outside of Ngouédi was inaugurated in Boko and in 1981, according to Dorier-Apprill, all the parishes of Brazzaville had therapeutic centers where people could come for healing. ${ }^{24}$

"The gift of writing" was first seen in Komono, in 1974, and is described by Andersson as manifesting when someone "attending to a service, in an ecstatic or inspired state, during the sermon or the singing, writes signs or takes illegible notes in a notebook. This gift, as the gift of speaking in tongues, demands

Conversion; Andersson, Väckelse; Å. Dalmalm, L'Eglise à l'épreuve de la tradition, La communauté Evangélique du Zaire et le Kindoki (Paris: EDITAF, 1985); Further reading includes the Journals of the various Missions (in Swedish) deposited at the Riksarkivet (National archives) in Stockholm, Sweden.

Andersson, Väckelse, 113; Interview with Philippe Louhemba, 18 February 2013. Dr. Louhemba is today among the foremost informants on the revival of the EEC.

Andersson, Väckelse. See also Elisabeth Dorier-Apprill, "Christianisme et therapeutique à Brazzaville," in Politique africaine 55 (Oct 1994), 133-139; For further reading see: Elisabeth Dorier-Apprill, "Environnement et santé à Brazzaville (Congo) : de l'écologie urbaine" à la géographie sociale." Doctoral dissertation, Paris 10, 1993. Ibid. 
an interpreter to be understood."25 I have personally seen this happening on numerous occasions. I have also asked people about the interpretations and some have answered that they will come "in due time." I return to that gift below, when commenting upon an event in March 2016.

\subsection{The Trip to Loukakou}

During the dry season in 1984, my wife and I accompanied Pastor Dembi from the parish of Mansimou to one of the outposts in the countryside. At Loukakou, a Centre Therapeutique (CT) was to be opened. A deaconess of the parish had "seen" in a dream people coming together to pray for the sick and people being healed drinking tisanes (potions) of various kinds in the mbongi (meeting-hut) at the center of the village. ${ }^{26}$ The dream had been reported to the pastor and the board had, after some discussion, decided that a center could be opened. We were to participate in the opening ceremonies.

On the day of the opening I awoke quite early and, when walking about the village, I saw the evangelist's wife stirring three huge aluminum pots on a fire with a big wooden spoon. The saucepans, of some $40-50$ liters, were boiling slowly. She grabbed a mug and, from a distance, I saw her plunge it into each of the pots in turn and take a small sip. Then she replaced the lids and continued stirring. Later in the day I asked her why she had tasted from the pots and she answered: "Well, one doesn't always know what kinds of diseases one has. No harm in getting cured."27 Later in the morning people came from the village and nearby villages and took part in the service and various consultations and, during the Sunday service, the Therapeutic Centre of Loukakou was officially recognized.

What struck me then, in 1984, was that to my knowledge one could not take a Revealed Medicine and use it in a prophylactic sense. If not properly used, the tisanes in the pots were nothing but plain plant teas. However, the evangelist's wife must have believed that the healing power was in the liquids - which is not what the charismatics engaged in the Revealed Medicine say. So, how does it work?

\section{4}

A Typical Therapeutic Center in the Early 197o's - the Lukunga Center In 1974 Pastor Jonathan Mayingani wrote his final paper on "Healing through the use of revealed plants", describing various healing services in three

\footnotetext{
25 Andersson, Väckelse, 167.

26 In the EEC, laypeople - mostly elders of the parish - may, after initiation, serve as laydeacons. The French word is diacre, which is a title serving both women and men.

27 Personal notes 7 April 1984.
} 
countryside parishes in the districts of Musana and Madzia and giving a very detailed description of buildings and equipment used at the Lukunga Center. It is as if, according to him, the structures are as important as the treatment given. However, he also talks about a woman, one Mrs Badidila, who, in spite of being illiterate, received the complete program for therapeutic sessions including Biblical texts to be read and a song to be sung - as a gift from the Holy Spirit. The song, according to Mayingani, reveals everything that is to happen: that people will disclose all their pains and then they will be healed. As the song is sung, people approach Mrs Badidila one by one, and tell her about their illnesses. The secretary, who is her husband, gives every patient a card on which the illness as well as the treatment is written. In the third verse, it is said: "fukameno bwabu ya luniakisa" (kneel and I shall heal). When this strophe is sung, everybody kneels and Mrs. Badidila prays for all who are kneeling, asking God to proceed with the healing of everyone present. When the singing has ended and while people are still on their knees, those who want to pray may do so. And the ceremony comes to an end as everybody takes part in the Lord's Prayer. On the morning of the following day, every sick person goes to the laboratory to receive the prescribed medicine. Some have brought bottles, and receive the medicine for free. Others pay a very modest sum for a bottle.

As everything is written on cards and in books, there are statistics available and Mayingani writes: "From 1969 to 1971, more than 886 brothers and sisters have found healing at Lukunga. In 1973 only, more than 1,093. During this period only 11 people have died. Most due to old age and only a few due to incurable illness." ${ }^{28}$

\section{$5 \quad$ Revealed Medicine in Brazzaville, in the 197os}

In the city of Brazzaville things, at the time, were a little more formal. One of the distinguished leaders of the Revealed Medicine in the district of Brazzaville was Mama Veronique Nsonde, a lady in her sixties and member of the huge Poto-Poto parish in the east of the city. Mama Veronique frequently told the story of how God showed her mission to her. In a dream she had seen a forest through which were walking small groups of people. As each group came into sight the names of medicinal plants, adapted to various illnesses, appeared over their heads. In the morning - still in her dream - she was told to bring a certain plant to her own, epileptic, mother and to pray for her healing.

28 Jonathan Mayingani, Guérisons au moyen de la Médicine Révélée. Mémoire de Fin d'Etudes. Unpublished (Brazzaville, 1974), 13-15. 
At the time when Mama Veronique had her dream, she was not allowed to begin practicing with the information it imparted. When she told her pastor he did not allow her to exercise her gift until they had gone to see Pastor Ndoundou at Ngouédi. Ndoundou was said to have the gift of discernment and was "very strong" in revealing whether people wanted to practice their gifts for their own benefit. However, after returning from Ngouédi, Mama Veronique was among those who were authorized to start the Therapeutic Centre at PotoPoto, in $1976 .^{29}$

I had the opportunity to meet with Mama Veronique in the early ' 8 os. She was, in spite of her age, a radiant woman who was very keen to tell us, young missionaries as we were, of the mighty things God had done in the Congo.

\section{Who are the Charismatics?}

The people who work at the therapeutic centers come from all groups of society. I have personally met quite a few. In the above description of the Lukunga Center we read that the woman in charge, Mrs. Babidila, was illiterate. But Mama Veronique of Poto-Poto was a respected nurse and member of the parish board, while in the Mayangui parish I met Tata Samba Diouf, a former teacher, who was one of the elders and taught me a lot about Revealed Medicine.

In 1983, Professor Levy Makany worked as chargé d'affaires for the People's Republic of Congo, in Ghana. One night he dreamed that he should resign from his post in Ghana and return to Brazzaville where God would give him a new job. ${ }^{30}$ Without knowing what kind of job to expect, he left Ghana with his family and returned to Brazzaville. After some months, he met with an old friend who told him that he in turn, in a dream, had seen Professor Makany open a hospital that was to receive "everybody, regardless of social status, religion or ethnic origin" in order to receive healing through prayer and the distribution of herbal medicines that were to be revealed. ${ }^{31}$ Towards the end of 1983 the Hôpital de Dieu (God's Hospital) was opened. It functions on an ecumenical basis, and representatives from all the recognized churches (EEC, Roman Catholic, Salvation Army, Evangelical Orthodox) are members of its board and

29 Interview with Louhemba, 13 February, 2013.

3o Interview with Levy Makany, 19 February, 2013.

31 Interview with Levy Makany, 19 February 2013. Professor Makany has been Rector of the Marien Ngouabi University, former Minister of Education under President Alphonse Massamba-Débat and former Secretary General of African universities. 
act as non-paid servants. One of the principles of the Hôpital de Dieu is that treatment should be totally free of charge and that the hospital should operate purely on the basis of financial gifts. ${ }^{32}$

I have visited the Hôpital de Dieu several times, carrying out interviews and gathering photographic material there. It is an interesting institution, which, thanks to Professor Makany's status, has become accredited by the government and is well regarded. The hospital consists of several buildings and is well organized. One enters a big hall, seating some 200 people, which is used for church services, giving testimonies, and conferences. For a few years (2013) the hospital has also had a documentation centre. Behind the hall are several buildings for treatment and for the distribution of medicines. Storage rooms and a garage are located in the garden behind the man building.

The weekly program is well defined:

Monday: The center opens to the public. People come and participate in the morning service, which takes about an hour and a half. Pastors from different denominations preach and, towards the end of the service, time is devoted to testimonies of healing. After the morning service people are received, in turn, at the Secretariat where they meet with those who have the gift of diagnosis. This meeting begins with individual prayer and intercession. Occasionally complicated situations arise: people may have visited a fetishist, be heavily indebted, in an unharmonious marriage, or experiencing complicated relations within the family. Those "cases" are guided to the pastor's office where the client may confess sins and get absolution. At the Secretariat, the client deposits the vessel appropriate for the kind of medicine she/he is to receive. Before the patient leaves the hospital the "oral vaccination" is given. ${ }^{33}$

There are five forms of treatment: (1) a tisane to be taken at specific times; (2) medicinal eye drops; (3) "scarification" in which the skin is cut with a razorblade and the medicine is rubbed in; (4) anointing, whereby the medicine is diluted in palm oil and worked into the skin of the patient through massage; and (5) "Tyoko", in which the medicine is diluted in hot water and the patient

32 Interview with Levy Makany, 19 February, 2013.

33 The oral vaccination consists of a potion based on the leaves of the herb Chenopodium album (Sv. Svinmålla). Dictionaries mention that Chenopodium album is commonly used in African traditional healing. 
inhales the vapors. Only the first treatment - tisane - can be auto-administered; the rest require that the patient visits God's Hospital.

Tuesday: Those who have the gift to collect plants leave the town by car or bus to go and find the herbs, plants, or wood required for the fabrication of medicines. Pieces of wood and plants that can be dried can be stored for some weeks in the storage rooms but many potions require fresh ingredients.

Wednesday: Medicines are prepared.

Thursday and Friday: These are "reception-days" when patients come to collect their medicine bottles or to receive the appropriate treatment. For those who so desire intercession is always available. ${ }^{34}$

\section{$8 \quad$ Revealed Medicine and the Confusion of the $1990 \mathrm{os}$}

Congolese society underwent dramatic change in the $1990 .{ }^{35}$ I worked in Brazzaville from 1989 to 1992 and, thereafter, conducted several periods of fieldwork there for my doctoral studies, some of which were carried out between the civil wars that afflicted the city. In 1992 the Mission Covenant Church of Sweden met with the EEC for discussions regarding future collaboration, including the future of medical collaboration. Although the "medicine through revealed plants" was spoken of as a "gift from God, for the benefit of a people deprived of economic means", numerous problem areas were presented. Some that need to be mentioned are:

- the tendency to align with purely spiritual practice whereby medical diagnostics and treatments are put aside;

- jealousy among the charismatics and their unwillingness to present their "products" to the broader mass of the population;

- the possibility that the centers will be transformed into lucrative businesses. ${ }^{36}$

In retrospect it suffices to study the list of participants at the meeting to notice that no representatives or practitioners of Revealed Medicine were present during the deliberations; the different centers had not yet created any national boards or common organizations. However, the EEC had a medical board

34 Fieldnotes and interview, 19 February 2013.

35 Suggested readings: Gaston-Jonas Kouvibidila, Histoire du multipartisme au Congo Brazzaville, tôme 1-3 (Paris,L'Harmattan, 2003); Anne Sundberg, "The Struggle for Kingship: Moses or Messiah - Ethnic war and the Use of Ethnicity in the Process of Democratization in Congo Brazzaville," in Ethnicity Kills, ed. Einar Braathen, Morten Böås, Gjermund Saether (Palgrave MacMillan, UK, 2000), 87-108.

36 Minutes, EEC, Brazzaville 1993, p. 35. 
supervising the work at its many dispensaries and clinics and these may have felt at threat from the therapeutic centers. As a result of the meeting a recommendation was made for the reorganization of the Oeuvre Médical which then should comprise four commissions: 1 ) the Commission of Dispensaries and Maternities; 2) the Commission of Pharmacies and Depots; 3 ) the Commission of Public Health; and 4) the Commission of medicine through revealed plants. ${ }^{37}$

Although the study group expressed its worry regarding the eventual creation of lucrative, local businesses, that did not happen. However, a number of "charismatics", benevolent workers at the various centers, began establishing kizingas at their homes. One of my informants told me that the privatization of Revealed Medicine was the biggest problem during the ' $90{ }^{38}{ }^{38}$ leading to a massive distrust among people, while the therapeutic centers in quite a few parishes fell apart. ${ }^{39}$ So, by the time the EEC was finally ready to incorporate the centers into its organization, the formerly strong presence of centers had almost dissolved. Throughout the '9os God's Hospital was one of the best functioning centers; however, it was not organized under the EEC but, rather, was a private venture that sought to be connected to the Ecumenical Council of Congo.

\section{9}

\section{The Young, the Revival and Revealed Medicine}

When I worked in the two Congos in the years from 2007 to 2010 , I occasionally visited therapeutic centers in Brazzaville. What struck me was that it was the same "old" people working there. The recruitment of younger collaborators did not seem to go very well. In 2013, the situation was the same and I went to talk with one of my former students, Pastor Samba, who worked as urban evangelist among the young in Brazzaville. During our long talk Pastor Samba repeatedly stressed that the young have a different spirituality or, at least, a spirituality which is expressed in other ways. The "Revival of 47 ", he said,

...belongs to the old, to a different generation at a time that was completely different. At that time the batata, the old men, could spend a whole day, or even half a week, at spiritual retreats or prayer meetings.

37 EEC, Brazzaville 1993. p. 36. CEuvre Médical is the Medical Office of the EEC.

38 Pastor Zoe has a long experience with Revealed Medicine. In his twenties, around 1980, he was assigned as responsible for the Centers of Traditional and Revealed Therapies in the Department of Kinkala (Responsable des Centres de Thérapies Traditionelles et Revellés), by the local political authorities.

Interview with J.C. Zoe, 3 August 2013. 
They had the time to go and find the plants that God revealed and they had the time to cook tisanes for hours. But "La jeunesse" [the young] are disconnected from that. The times have changed; the world changes with every second and we, the young, are with that world. Europe and the West have captivated the young and the young are looking for completely new strategies to survive in today's rapidly changing world. The Church cannot impose its Africanity on the young who want to be modern. The young are no longer typically African. ${ }^{40}$

On my asking how the young relate to the therapeutic centers, he answered that "there will always be some young who integrate into that movement, as there will be young who integrate into and sing in the Kilombo choruses." ${ }^{.1} \mathrm{But}$ these young, he continued, "are often those that have grown up in the village and have become orphans and have moved to town to live with the extended family. They do not easily integrate with the youth chorus or the Bible study groups." ${ }^{2}$

Pastor Samba would never go to a therapeutic center to find a cure for some ailment. He informed me that the Mayangui parish has its own hospital where he goes if needs medical treatment. When I tell him that Mayangui also has a therapeutic center he says that he is not confident in that kind of healing. God has inspired the parish to build a hospital with "...Western medicine, doctors, nurses and a pharmacy selling scientifically developed medicines. Isn't that better?"43

In a later talk, that same day, I found Pastor Samba at his home with a group of young people of his age. Pastor Samba mentioned our earlier interview and they began a long discussion of modern forms of sorcery versus various forms of healing and liberation from sorcery's effects. It became quite apparent that all kinds of magic are used by university students - in order to obtain higher grades in exams, for example. It became clear that although the young do not want Africanity to be imposed upon them, they live in a society which in many ways is very different from the Scandinavian, from which I come.

During the discussion, a young woman mentioned that she had heard about a hospital in town which was, as she saw it, nothing but a formalized, large-scale

$40 \quad$ Interview with G. Samba, 3 July 2013.

41 The Kilombo chorus is also a product of the Revival. It is established around one or a few persons who have received songs from God On Kilombo, cf. Celestin Bissila,. Recherche Authentique Hymnologique et Instrumentale dans l'EEc. Unpublished final memoir. Fac. De Theologie Protestante de Yaoundé, Cameroun, 1985.

42 Interview with G. Samba, 3 July 2013.

43 Interview with G. Samba, 3 July 2013. 
kizinga: one with blocks and wards just a like a normal hospital, but where the treatment was the same as at the therapeutic centers. She also said that at that hospital they had an oral vaccination that everybody received and that had healed quite a few, "Just like that." The statement caused a number of those present to laugh and somebody said, "That soup ought to be distributed for free all over Brazzaville."44

Two weeks before writing this chapter, I returned from a month in Brazzaville. I did not have time personally to visit God's Hospital but I had collected some published material and conducted a few interviews. I visited the therapeutic center of the Bacongo Parish and found "the same old people." Not much had changed. However, I was told that the EEC had finally, in the last couple of years, established a National Board for the supervision of those centers that were still functioning. To my surprise the Mayangui parish had reopened its center and new centers had been opened in a few of the younger parishes. God's Hospital has now been in service for 33 years, since 1983, and the new documentation center is well used. Professor Makany, now in his eighties, is still going strong and continues to lecture at the Marien Ngouabi University. He is still, as Professor of Botanics, an authority in the Republic of Congo.

MaGloire, a lay-person of the EEC, had received four years of education at the l'ENAm (L'École Nationale d'Administration et de Magistrature), a highlevel school for employees of the national administration. He told me that the Lord had got him into that school and finally had given him a position as Director of Human Resources at the Mairie de Brazzaville. He had held this position for another four years when the Lord one day said to him, "You have done your work well, now come and work for me."45 MaGloire then told me that he had been among those who, after a spiritual retreat in Kindamba (2014), had formed a national prayer group with members from different parishes throughout the southern districts of the EEC, from Brazzaville to Pointe Noire. As a member of the Bacongo parish, he was one of the Brazzaville group of intercessors.

The special gift that the Lord had given MaGloire was that he received messages through the Holy Spirit, which could go like this:

44 Taped conversation with G. Samba and friends, 7 March 2013.

45 Interview with MaGloire, 21 February 2016. 
[T] he Lord tells me: "Take your notebook and a pen and go to work." So I grab my notebook and go to work. Often this happens at night. Like, when we were in Musana, with Papa Hans. I was at work for the Lord and Papa Hans came and asked: "What are you doing at this time, in the middle of the night?" I told him that I would explain later. You see, for him to see someone who fills a 112-page notebook, working all night...He will say: "But what are you doing, scribbling rapidly like that, like an idiot?"

...You see, I receive information on medicines. When I begin writing I am informed that this is a medicine for the treatment of, for example, malaria. But I have no idea what the posology is or how to administer it. I just do the writing. In the morning I call an elder, a woman who has the gift of interpretation. She now writes down what the Lord has told me. Then we archive the original text as well as the interpretation. ${ }^{46}$

Like so many others in the EEC, MaGloire has received the "gift of writing." As stated above, this is considered one of the gifts of the 1947 Revival, a gift that was confirmed by Tata Ndoundou and, as such, it has been extensively practiced in the EEC. Hundreds of notebooks are stored at some parishes without ever having been interpreted. In consequence, the gift has been criticized by many as sheer destruction, whereas others, often the writers themselves, have held the position that interpretation will come when the Lord so decides. In this case, the interpretation may come the following day as an interpreter is at hand. MaGloire also told me that sometimes, when they intercede for a specific person, the Lord can tell him to get his notebook and pen and to write down a specific treatment for the client. Then it comes with details such as quantities and very often it is also "said" that the price shall be 200 or $300 \mathrm{CFA}$, not more (about USD 0.5).

Interestingly MaGloire sees the specific-person case as arbitrary. The Lord has told the prayer group that the Republic of Congo shall be developed through the churches and that the churches shall engage in establishing farms, fisheries, and various kinds of small productive units and in promoting "scientific Revealed Medicine." MaGloire - and the prayer group - believe that the medical prescriptions of a general character that he receives via the Holy Spirit must be tested by pharmacologists and, if they work, must be exploited in ways that are profitable to all churches. ${ }^{47}$

$46 \quad$ Interview with MaGloire, 21 February 2016.

47 Interview with MaGloire, 21 February 2016. 


\section{Conclusion}

When the Portuguese came to Kongo at the end of the $15^{\text {th }}$ century they adopted the already existing local name for God, Nzambi, the creator of all and the sustainer of life and society. Since then there has been an ongoing process of adaptation and inculturation. Christianity has been adapted to Kongo culture and Kongo culture to Christianity.

There are, in my opinion, many similarities between spiritually given healing through revealed plants and traditional plant therapies. Tata Samba Diouf, one of the elders of the Mayangui congregation, when asked, denied all connections between what people "knew" from tradition and what was seen in visions or dreams. He was very rigid in his position that what was revealed by God through this "gift of the plants" had nothing to do with what God had revealed to his forefathers, in the old times. "Then the forefathers knew that this plant will heal this illness and that plant will heal that illness. Today it is different," he said. ${ }^{48}$

Today this plant can cure that illness and that plant can cure this illness because, more important than the plants, is the confession of sins, the intercession and the inspired treatment that God has told us to give. We pray for every single person and we take care of every single person. It is not just a distribution of medicines. ${ }^{49}$

Tata Diouf's argument is also endorsed by the EEC wherein it has always been underlined that any resemblance is coincidental. God - Nzambi - has revealed the medicinal qualities of plants and how to use them for the treatment of various illnesses. My objection to that is that the same Nzambi also provided knowledge and wisdom to the forefathers and that this knowledge has then been traded down the generations. Thus, it cannot be considered "pagan" to use traditional methods to heal with plants.

One reason that the discussion is not very open within the EEC may be because the constitution of the EEC, and its disciplinary documents, prohibit discussion of elements referring to "old traditions." 50 It is thus forbidden to relate to and discuss personalities like the traditional nganga (the priest) or the

\footnotetext{
48 Personal diary, 1984

49 Ibid.

50 EEC 1990 and EEC 1998. The original documents were established in the 196os by Swedish missionaries, and the Congolese church leaders, unfortunately, tend to venerate what was written by the "Elders."
} 
sorcerer, and their respective activities. In my opinion, many of the problems that the EEC faces today, regarding modern forms of fetishism and sorcery, could have been overcome if the teachings of Buana Kibongi had been popularized and made accessible to the pastoral students of the EEC and to its parishes and members. ${ }^{51}$ The constitution, in fact, hinders a local, thorough study and discussion of similarities between the old and the new, rendering the rereading of Kongo traditions rather difficult.

I find Pastor Samba's comment - that the young of today do not want to be pushed into "some kind of old Africanity" - interesting. I have collected plenty of evidence indicating that students use modern forms of sorcery or fetishism to gain an extra portion of life force in order to perform better in university exams and a range of other life situations. That same force, however, is also believed to be channeled through treatments with revealed plants. The woman with travel-document problems, for example, searched for healing when suffering from an illness that could be ranged under kimbevo ya sanse, or bad luck. Professor Makany and Mr. MaGloire also combine the old with the new in various ways. Makany has systematized the kizinga and shaped it into God's Hospital, where the Holy Spirit acts through vaccinations, psychotherapy, and medication of the whole person in a setting and with personnel that could make Western-medicine hospitals envious. MaGloire, on the other hand, feels it is possible to systematize spiritually given knowledge to heal not only specific persons but the whole Congolese society. This study shows how a wellestablished, mission-based church in Brazzaville, Congo, struggles to keep alive one aspect of the experience of a powerful revival (of 1947) that transformed the entire church, while at the same time, the same Holy Spirit fuels other expressions of Christianity.

Africa, someone said, will always remain Africa. And with the aid of mobile phones, the Internet and migrating Africans we meet its enchanted worldviews, its interpretations of Christianity and its expressions of spirituality in every corner of the earth. Let us there meet each other with interest and curiosity, but also with respect and love.

$51 \quad$ Raymond Buana Kibongi (1929 - 1998) in the years $1963-1967$ was Principal of the Theological Seminary of the EEC. Beside Daniel Ndundu he was one of the leaders of the revival of 1947 . 


\section{References}

Åhman, Bertil. Daniel Ndoundou, väckelseledare i den Evangeliska kyrkan i Kongo. Studia Missionalia Svecana CXIII, Uppsala, 2014.

Andersson, Efraim. Väckelse och andra kristna folkrörelser i Kongo. Missio, vol. 12 edited by Gösta Stenström. Uppsala: Svenska Institutet för Missionsforskning, 1997.

Batsikama ba Mpuya ma Ndawla, Raphaël. L'Ancien Royaume du Congo et les baKongo. Paris: L'Harmattan, 1999.

Baudin, Pierre Fetishism and Fetish worshippers. New York: Benzinger Brothers, 1885. Quoted in Laurenti Magesa. African Religion: the moral traditions of abundant life. Maryknoll, N.Y. Orbis Books, 1997.

Bissila, Celestin. Recherche Authentique Hymnologique et Instrumentale dans l'EEC. Unpublished final memoire. Fac. De Theologie Protestante de Yaoundé, Cameroun, 1985

Dalmalm, Åsa. L'Eglise à l'épreuve de la tradition, La communauté Evangélique du Zaire et le Kindoki. Paris: EDITAF, 1985.

De Rosny, Eric. L'Afrique des guérisons. Paris: Editions Karthala, 1992.

Dorier-Apprill, Elisabeth. "Environnement et santé à Brazzaville (Congo): de l'écologie urbaine' à la géographie sociale." Doctoral dissertation, Paris 10, 1993.

Dorier-Apprill, Elisabeth. "Christianisme et thérapeutique à Brazzaville." Politique africaine 55 (Oct 1994): 133-139.

Geschiere, Peter. Witchcraft, Intimacy and Trust. Chicago: University of Chicago Press, 2013.

Ikenga-Metuh, Emefie. The shattered Microcosm: a critical survey of explanations on conversion in Africa. Paper presented at the Religion, Development and African Identity Conference. Uppsala, 16-21st of August, 1984. (1987)

Kouvibidila, Gaston-Jonas. Histoire du multipartisme au Congo Brazzaville, tôme 1-3. Paris: L'Harmattan 2003.

Laman, Karl Edward. “The Kongo II." In Studia Ethnographica Upsaliensia, vol VIII, edited by Sture Lagerkrantz. Uppsala: Almkvist Wiksell, 1957.

MacGaffey, Wyatt. Religion and Society in Central Africa: The Bakongo of Lower Zaïre. Chicago: University of Chicago Press, 1986.

Magesa, Laurenti. African Religion: the moral traditions of abundant life. Maryknoll, N.Y. Orbis Books, 1997 .

Mahaniah, Kimpianga. La maladie et la guérison en milieu Kongo. Kinshasa: EDICVA, 1982.

Mayingani, Jonathan. Guérisons au moyen de la Médicine Révélée. Mémoire de Fin d'Etudes. Brazzaville, 1974 (unpublished).

Mbiti, John S. African Religions and Philosophy. London, Ibadan, Nairobi: Heinemann, 1969 . 
McGuire, Meredith B. Religion, the Social context, 3rd ed. Belmont, California: Wadsworth Publishing Company, 1992.

Sundberg, Anne. Ethnic War and Ethnic Cleansing. Unpublished dissertation, Lund, 1999.

Sundberg, Anne. "The Struggle for Kingship: Moses or Messiah - Ethnic war and the Use of Ethnicity in the Process of Democratization in Congo Brazzaville." In Ethnicity Kills, edited by Einar Brathen, Morten Böås, Gjermund Saether, 87-108. Palgrave MacMillan, UK, 2000.

Sundberg, Carl. Conversion and Contextual conceptions of Christ. Doctoral Dissertation. Studia Missionalia Svecana LXXXI, Uppsala, 2000.

Widman, Ragnar. Trosföreställningar i Nedre Zä̈re från 188o-talet. Falköping: Gummessons, 1979 . 